\title{
DNA Binding Properties of Two Ruthenium(III) Complexes Containing Schiff Bases Derived from Salicylaldehyde: Spectroscopic and Electrochemical Evidence of CT DNA Intercalation
}

\author{
Nevzeta Ljubijankić, Adnan Zahirović, Emir Turkušić, \\ and Emira Kahrović \\ Department of Chemistry, Faculty of Science, University of Sarajevo, \\ Zmaja od Bosne 35, 71000 Sarajevo, Bosnia and Herzegovina
}

RECEIVED NOVEMBER 28, 2012; REVISED MAY 15, 2013; ACCEPTED MAY 22, 2013

\begin{abstract}
The interaction of CT DNA by two anionic Ru(III) complexes with $N$-substituted salicylidenimine ligands was investigated by spectroscopic titration and cyclic voltammetry. The result gives a surprising evidence for intercalation of DNA by the negatively charged complex species containing non typical intercalating ligands with $K_{\mathrm{b}}$ of order $10^{4} \mathrm{M}^{-1}$. Na[RuCl $\left.2(\mathrm{~N}-\mathrm{R}-5-\mathrm{X} \text {-salim) })_{2}\right]$, where R represents butyl or phenyl and $\mathrm{X}=\mathrm{H}, \mathrm{Cl}$, were characterized on the basis of elemental analysis, MALDI-TOF mass spectrometry, infrared, UV / visible spectroscopic measurements and cyclic voltammetry. (doi: $10.5562 / \mathrm{cca} 2216)$
\end{abstract}

Keywords: Schiff base, ruthenium, DNA intercalation, spectroscopy, cyclic voltammetry

\section{INTRODUCTION}

Ruthenium compounds have been the subject of great interest and impressive development in last decades for many reasons, especially due to their catalytic ${ }^{1-4}$ and anticancer activities. ${ }^{5-11}$ Ruthenium generally demonstrates affinity toward $\mathrm{N}$-donor molecules such as proteins and DNA. The mechanism of the action of antitumor-active ruthenium compounds is not entirely known. Closely, it is thought that the complexes containing chlorides, or other easily leaving groups, can hydrolyze in vivo, allowing the covalent binding of the nucleobases from DNA to ruthenium. ${ }^{12}$ Many $\mathrm{Ru}(\mathrm{II})$ and $\mathrm{Ru}(\mathrm{III})$ compounds with numerous different ligands are reasonably synthesized and investigated for the purpose of possible application in medicine and catalysis. There are no many complexes containing Schiff bases derived from salicyladehyde described in literature, although such ligands generally show considerable stereochemical flexibility and capability to tune the reduction potential of metal center, acting as $N$ - or $N, O$ ligands. ${ }^{13,14}$ Some of them are described as very good catalysts in organic synthesis because the presence of salicylaldimine in the molecule increases the stability and catalytic activity. ${ }^{15}$ Such ligands are derived from 2,4,6-tris substituted phenylamines and salicylaldehyde containing attached quaternary ammonium group to increase hydrophilic character. ${ }^{16-18}$ Furthermore, some ruthenium complexes with salicyladi-mines showed significant biological activity against some bacteria, in contrast to the less active free ligands. ${ }^{19}$ In addition, two dichloro-bis[ $N$-phenyl-5substituted-salicylideniminato- $N, O$ ]ruthenate(III) are described as electrochemical mediators for the low potential amperometric determination of ascorbic acid. $^{20,21}$

We aimed to investigate interaction of $\mathrm{Ru}(\mathrm{III})$ complexes containing simple Schiff bases derived from salicylaldehyde with DNA and we report spectroscopic and electrochemical evidence of CT DNA intercalation by two dichloro-bis[ $N$-substituted-5-X-salicylideniminato- $N, O$ ]ruthenate(III) compounds, hereinafter $\mathrm{Na}\left[\mathrm{RuCl}_{2}(\mathrm{~N}-\mathrm{R}-5-\mathrm{X} \text {-salim })_{2}\right]$ where $\mathrm{R}$ represents butyl or phenyl, while $\mathrm{X}=\mathrm{H}, \mathrm{Cl}$.

\section{EXPERIMENTAL}

Chemicals were purchased from commercial sources and used without further purification. Calf thymus DNA (CT DNA) was purchased from Sigma Aldrich.

\footnotetext{
* Author to whom correspondence should be addressed. (E-mail: emira_kahrovic@yahoo.com)
} 


\section{Synthesis}

Preparation of Ligands

$N$-substituted-5-X-salicylidenimines, hereinafter N-R-5XsalimH $\left(\mathrm{R}=\mathrm{C}_{4} \mathrm{H}_{9}, \mathrm{C}_{6} \mathrm{H}_{5}, \mathrm{X}=\mathrm{H}, \mathrm{Cl}\right)$ were prepared by simple condensation of butyl amine with salicylaldehyde and aniline with 5-chlorosalicylalde-hyde in molar ratio $1: 1$ at room temperature. Solid $N$-phenyl-5-chlorosalicylidenimine was recrystallized from ethanol at $70{ }^{\circ} \mathrm{C}$ with $70-80 \%$ yield.

Preparation of Complexes $\mathrm{Na}\left[\mathrm{RuCl} \mathrm{l}_{2}(\mathrm{~N}-\mathrm{R}-5-\mathrm{X} \text {-salim })_{2}\right]$ Sodium dichloro-bis[N-phenyl-5-chlorosalicylideniminato- $\mathrm{N}, \mathrm{O}]$ ruthenate(III), $\mathrm{Na}\left[\mathrm{RuCl}_{2}(\mathrm{~N}-\mathrm{Ph}-5 \text {-Cl-salim })_{2}\right]$. Dichloro-bis[ $N$-phenyl-5-chlorosalicylideniminato-

$N, O]$ ruthenate (III), hereinafter $\mathrm{Na}\left[\mathrm{RuCl}_{2}(\mathrm{~N}-\mathrm{Ph}-5-\mathrm{Cl}-\right.$ salim) $)_{2}$, was prepared according to the published procedure $^{22}$ and precipitated as sodium salt. $0.46 \mathrm{~g}$ ( $2 \mathrm{mmol}$ ) $\mathrm{N}-\mathrm{Ph}-5-\mathrm{Cl}$-salimH in $30 \mathrm{~mL}$ ethanol absolute was added to the solution of $0.26 \mathrm{~g}(1 \mathrm{mmol})$ $\mathrm{RuCl}_{3} \cdot 3 \mathrm{H}_{2} \mathrm{O}$ in absolute alcohol $(10 \mathrm{~mL})$. The mixture was refluxed for 3 hours at $65-70{ }^{\circ} \mathrm{C}$ and the volume was reduced in rotary evaporator to the half of the initial volume. The precipitation was performed by adding the water solution of $0.058 \mathrm{~g} \mathrm{NaCl}(1 \mathrm{mmol}) / 1 \mathrm{~mL}$. The dark green solid was washed with diethyl ether and dried over $\mathrm{P}_{2} \mathrm{O}_{5}$. Yield: $55 \%$.

Anal. Calc. for $\mathrm{NaRuC}_{26} \mathrm{H}_{18} \mathrm{Cl}_{4} \mathrm{O}_{2} \mathrm{~N}_{2} ; \quad$ (\%): C, 49.30; H, 2.86; N, 4.42. Found (\%): C, 48.36; $\mathrm{H}, 2.91 ; \mathrm{N}, 4.21$. MALDI-TOF MS $\mathrm{m} / \mathrm{z}: 633.91$ $\left(\left[\mathrm{C}_{26} \mathrm{H}_{18} \mathrm{Cl}_{4} \mathrm{O}_{2} \mathrm{~N}_{2} \mathrm{Ru}\right]^{-}, 100 \%\right)$. IR(KBr) $v_{\max } / \mathrm{cm}^{-1}$ : 1583 vs $(\mathrm{C}=\mathrm{N}), 1352 \mathrm{~m}(\mathrm{C}-\mathrm{O}$ phen $), 424 \mathrm{w}\left(\mathrm{Ru}^{-} \mathrm{O}\right)$, $669 \mathrm{w}(\mathrm{Ru}-\mathrm{N})$. UV / Vis $\left[\mathrm{CH}_{2} \mathrm{Cl}_{2}\right], \lambda_{\max } / \mathrm{nm}: 340$ and $495\left(\varepsilon / \mathrm{M}^{-1} \mathrm{~cm}^{-1}\right): 6600$ and 4144.

Sodium dichloro-bis[N-butylsalicylideniminatoN,O]ruthenate(III), $\mathrm{Na}\left[\mathrm{RuCl}_{2}(\mathrm{~N}-\mathrm{Bu} \text {-5-H-salim })_{2}\right]$. To the solution of $\mathrm{RuCl}_{3} \cdot 3 \mathrm{H}_{2} \mathrm{O}(0.10 \mathrm{~g}, 0.38 \mathrm{mmol})$ in $5 \mathrm{~mL}$ absolute ethanol, $0.76 \mathrm{mmol}$ freshly prepared butylsalicylidenimine was added. Reaction mixture was kept at $80{ }^{\circ} \mathrm{C}$ within 90 minutes in rotary evaporator whereby the resulting solution has changed the color from brown to dark green. Precipitation was performed with $1 \mathrm{~mL}$ water solution of $\mathrm{NaCl}$ $(0.02 \mathrm{~g}, 0.38 \mathrm{mmol})$. The resulting solution was kept overnight in ice-salt bath afterward the dark solid was filtered off and washed with ice-cold diethyleter. Yield: $43 \%$.

Anal. Calc. for $\mathrm{NaC}_{22} \mathrm{H}_{28} \mathrm{Cl}_{2} \mathrm{O}_{2} \mathrm{~N}_{2} \mathrm{Ru}$; $\mathrm{Na}^{+}\left[\mathrm{RuCl}_{2} \mathrm{C}_{22} \mathrm{H}_{28} \mathrm{O}_{2} \mathrm{~N}_{2}\right]^{-} ; \quad$ (\%): C, 48.30; H, 5.16; $\mathrm{N}$, 5.12. Found (\%): C, 48.06; H, 5.28; N, 4.81. MALDI-TOF MS $m / z: 524.0604\left(\left[\mathrm{RuCl}_{2} \mathrm{C}_{22} \mathrm{H}_{28} \mathrm{O}_{2} \mathrm{~N}_{2}\right]^{-}\right.$, $100 \%)$. IR(KBr) $v_{\max } / \mathrm{cm}^{-1}: 1606$ vs $(\mathrm{C}=\mathrm{N}), 1305 \mathrm{~m}$ $(\mathrm{C}-\mathrm{O}$ phen $), 404 \mathrm{w}(\mathrm{Ru}-\mathrm{O}), 669 \mathrm{w}(\mathrm{Ru}-\mathrm{N}) . \mathrm{UV} / \mathrm{Vis}$ $\left[\mathrm{CH}_{2} \mathrm{Cl}_{2}\right], \lambda_{\max } / \mathrm{nm}: 415,\left(\varepsilon / \mathrm{M}^{-1} \mathrm{~cm}^{-1}\right): 1408$.

\section{Physical Measurements}

Elemental analyses were performed on a Perkin Elmer 2400 Series CHNS/O Analyzer. Mass spectra were obtained on a matrix-assisted laser desorption / ionization-time-of-flight MALDI-TOF/TOF mass spectrometer (4800 Plus MALDI TOF/TOF analyzer, Applied Biosystems Inc., Foster City, CA, USA) equipped with Nd:YAG laser operating at $355 \mathrm{~nm}$ with firing rate $200 \mathrm{~Hz}$ in the negative ion reflector mode. 1600 shots per spectrum was taken with mass range 10-1500 Da, focus mass $500 \mathrm{Da}$ and delay time $100 \mathrm{~ns}$. Small amount of sample (on pipette tip) was resuspended in $10 \mu 1$ of DHB MALDI matrix $(5 \mathrm{mg} / \mathrm{mL}$; dissolved in $50 / 50$ acetonitrile/water, $v / v$ ) and $1 \mu \mathrm{l}$ was spotted on MALDI plate. The spectrum was internally calibrated providing measured mass accuracy within $5 \mathrm{ppm}$ of theoretical mass riboflavin and 3-aminosalicylic acid were used as internal calibrants in negative ion mode.

The infrared spectra were recorded as $\mathrm{KBr}$ pellets on a Perkin Elmer spectrum BX FTIR System in the region $4000-400 \mathrm{~cm}^{-1}$. UV/visible spectra, hydrolyses and CT DNA binding were measured on a Perkin Elmer lambda 35 spectrophotometer. Hydrolysis experiments were performed by adding the concentrated solution of complexes in DMSO to water buffered solutions (phosphate buffer, $\mathrm{pH}$ 7.5). The stock solution of CT DNA was prepared in Tris- $\mathrm{HCl}$ buffer at $\mathrm{pH} 7.4$ and stored at $4{ }^{\circ} \mathrm{C}$ maximally $1-4$ days. The concentration of DNA was calculated on the basis of extinction coefficient $6600 \mathrm{M}^{-1} \mathrm{~cm}^{-1}$ at $260 \mathrm{~nm} \cdot{ }^{23}$ The purification of DNA by phenol extraction methods improved the ratio of UV absorbance at 260 and $280 \mathrm{~nm} A_{260} / A_{280} c a .1 .8$, indicating that DNA was satisfactory free from proteins. The absorption of DNA itself was removed by adding the same amount of DNA in reference solutions as in ruthenium complex-DNA solutions. Concentrated stock solutions of complexes were prepared by initial dissolving compounds in small amount of DMSO and diluting to the required concentrations.

Cyclic voltammograms of $\mathrm{Na}\left[\mathrm{RuCl}_{2}(\mathrm{~N}-\mathrm{R}-5-\mathrm{X}-\right.$ salim $)_{2}$ ] were recorded on an electrochemical workstation Autolab potentiostat/galvanostat (PGSTAT 12) in DMF ( $N, N$-dimethylformamide) solution with sodium perchlorate as supporting electrolyte using glassy carbon working electrode and $\mathrm{Ag} / \mathrm{AgCl}$ reference electrode in the range of potential of -1.5 to $+0.1 \mathrm{~V}$, with scan rate rate $0.8 \mathrm{~V} \mathrm{~s}^{-1}$. Working electrode was polished prior to measurements with $1 \mu \mathrm{m}$ diamond paste. Electrochemical titrations of ruthenium compounds with $\mathrm{CT}$ DNA were recorded by cyclic voltammetry in Tris- $\mathrm{HCl}$ buffered water solution ( $\mathrm{pH}$ 7.4), at ambient temperature in $5 \mathrm{~mL}$-volume conical compartment self-made 
cell. The volume of the cell is adapted to the experiments meaning to the required volumes of $\mathrm{Na}\left[\mathrm{RuCl}_{2}(\mathrm{~N}-\right.$ $\mathrm{R}-5$-X-salim $)_{2}$ ] solutions $(2 \mathrm{~mL})$ and added $\mu \mathrm{L}$-amounts (0-60) of CT DNA.

\section{RESULTS AND DISCUSSION}

\section{Synthesis and Spectroscopic Studies}

Synthesis

$\mathrm{Na}\left[\mathrm{RuCl}_{2}(\mathrm{~N}-\mathrm{R}-5-\mathrm{X} \text {-salim) })_{2}\right]$ compounds were synthesized from $\mathrm{RuCl}_{3}$ and freshly prepared ligands, butylsalicylidenime $\left(\mathrm{R}=\mathrm{C}_{4} \mathrm{H}_{9}, \mathrm{X}=\mathrm{H}\right)$ and $\mathrm{N}$-phenyl-5-chlorosalicylidiemine $\left(\mathrm{R}=\mathrm{C}_{6} \mathrm{H}_{5}, \mathrm{H}=\mathrm{Cl}\right)$, in absolute ethanol solutions in molar ratio $1: 2$. The water suspended in liquid Schiff base was not removed before the use because the synthesis of final product was not affected by the presence of water; moreover it is known that, in some cases, the traces of water in butylsalicylidenimine assists replacement of leaving group by Schiff base in starting compound. ${ }^{24}$ The precipitations of anionic complexes were performed by water solution of sodium chloride. The dark green solids are quite stable in air, insoluble in water, soluble in acetonitrile, DMF, acetone, ethyl alcohol, DMSO, $\mathrm{CH}_{2} \mathrm{Cl}_{2}$. The molar ratio of ruthenium and Schiff bases had to provide coordination of two anionic $O, N$ ligands, keeping in octahedral environment of ruthenium, two chlorides as easily leaving groups. The characterization of compounds is based on elemental $\mathrm{CHN}$ analytical data, mass spectrum MALDI-TOF (Matrix Assisted Laser Desorption / Ionization; Time of flight mass analyzer), infrared and UV / visible spectroscopic measurements. Mass spectra showed molecular ions $\left(\mathrm{M}^{-}\right)$at $m / z(100 \%)=524.06$ which corresponds to $\left[\mathrm{C}_{22} \mathrm{H}_{28} \mathrm{Cl}_{2} \mathrm{O}_{2} \mathrm{~N}_{2} \mathrm{Ru}\right]^{-}$and $\mathrm{m} / \mathrm{z}$ (100\%) found for $\left[\mathrm{C}_{26} \mathrm{H}_{18} \mathrm{Cl}_{4} \mathrm{O}_{2} \mathrm{~N}_{2} \mathrm{Ru}\right] 633.91$.

\section{Infrared Spectroscopy}

Infrared spectra of titled compounds and free ligands clearly demonstrate the mode of binding via azomethine nitrogen and deprotonated phenolic oxygen to ruthenium strongly supporting the octahedral structure of the compounds. Strong absorptions at 1583 and $1606 \mathrm{~cm}^{-1}$ in $\mathrm{Na}\left[\mathrm{RuCl}_{2}(\mathrm{~N}-\mathrm{Ph}-5-\mathrm{Cl} \text {-salim) })_{2}\right]$ and

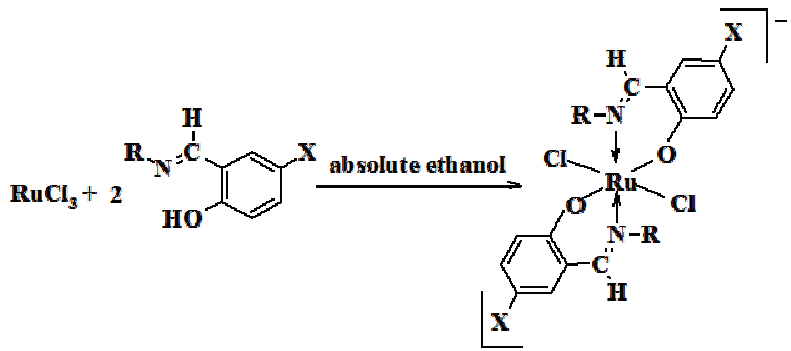

Figure 1. Scheme of preparation of $\mathrm{Na}\left[\mathrm{RuCl}_{2}(\mathrm{~N}-\mathrm{R}-5-\mathrm{X}-\right.$ salim) $)_{2}$; $\mathrm{R}=\mathrm{C}_{4} \mathrm{H}_{9}(\mathrm{Bu}) ; \mathrm{C}_{6} \mathrm{H}_{5}(\mathrm{Ph}) ; \mathrm{X}=\mathrm{H}, \mathrm{Cl}$.
$\mathrm{Na}\left[\mathrm{RuCl}_{2}(\mathrm{~N}-\mathrm{Bu} \text {-salim })_{2}\right]$ are assigned to the stretching frequency of $-\mathrm{CH}=\mathrm{N}-$, compared to the frequencies at 1615 and $1633 \mathrm{~cm}^{-1}$ in free ligands, respectively. The shift of the frequencies after coordination toward lower wavenumbers for 32 and $27 \mathrm{~cm}^{-1}$ is a proof of strongly bound azomethine nitrogen on ruthenium. Taking into account the shifts as the rough measure of weakening of $\mathrm{C}=\mathrm{N}$ from azomethine the absorptions at $669 \mathrm{~cm}^{-1}$ were assigned to $\mathrm{Ru}-\mathrm{N}$ in both compounds. On contrary, phenolic $\mathrm{C}-\mathrm{O}$ bond shows shift from 1271 and $1280 \mathrm{~cm}^{-1}$ in corresponding free ligands to 1305 and $1352 \mathrm{~cm}^{-1}$ in $\mathrm{Na}\left[\mathrm{RuCl}_{2}(\mathrm{~N}-\mathrm{Ph}-5-\mathrm{Cl} \text {-salim) })_{2}\right]$ and $\mathrm{Na}\left[\mathrm{RuCl}_{2}(\mathrm{~N}-\mathrm{Bu} \text {-salim })_{2}\right]$ as a result of increased electronic density on $\mathrm{C}-\mathrm{O}(\mathrm{Ru})$ after deprotonization of $\mathrm{C}-\mathrm{O}(\mathrm{H})$. The absorptions in the region $2850-2900 \mathrm{~cm}^{-1}$ were assigned to $\mathrm{CH}$ vibrations while moderate absorption at $1518 \mathrm{~cm}^{-1}$ belongs to skeletal $\mathrm{C}=\mathrm{C}$ vibrations. The weak absorptions, appeared around $425 \mathrm{~cm}^{-1}$ after coordination of Schiff bases, were attributed to $\mathrm{Ru}-\mathrm{O}$.

\section{UV/Visible Spectroscopy}

Electronic spectra of free Schiff bases and corresponding complexes were recorded in $\mathrm{CH}_{2} \mathrm{Cl}_{2}$ solutions. $\mathrm{Na}\left[\mathrm{RuCl}_{2}(\mathrm{~N}-\mathrm{Bu}-5-\mathrm{H} \text {-salim })_{2}\right]$ exhibits one broad absorption band centered about $415 \mathrm{~nm}$ arising from intraligand transition of whole molecule of Schiff base. Compared to free ligand, when $\mathrm{Ru}-\mathrm{N}$ bond is formed, the lone pair on nitrogen atom becomes stabilized and absorption assigned to $\mathrm{n} \rightarrow \pi^{*}$ showed hypsohromic shift (blue shift) for $7 \mathrm{~nm}$. In $\mathrm{Na}\left[\mathrm{RuCl}_{2}(\mathrm{~N}-\mathrm{Ph}-5-\mathrm{Cl}-\right.$ salim $)_{2}$ ] this absorption appears around $495 \mathrm{~nm}$. Weakly defined broad absorption centered around $350 \mathrm{~nm}$, assigned to the transition of $-\mathrm{HC}=\mathrm{N}$ - group, is superimposed by $\mathrm{Cl} \rightarrow \mathrm{Ru}(\mathrm{III}) \mathrm{LMCT}$ transition in $\mathrm{Na}\left[\mathrm{RuCl}_{2}(\mathrm{~N}-\mathrm{Bu}-5-\mathrm{H} \text {-salim) })_{2}\right]$ while in phenyl derivative a well defined band appears around $338 \mathrm{~nm}$. Weak broad absorption for both compounds, centered on $600 \mathrm{~nm}$ in the region of d-d spin allowed transition of low spin $\mathrm{t}_{2 \mathrm{~g}}{ }^{5} \mathrm{Ru}(\mathrm{III})$, can be assigned to $\left({ }^{2} \mathrm{~T}_{2 \mathrm{~g}} \rightarrow\right.$ $\left.{ }^{2} \mathrm{~A}_{2 \mathrm{~g}}\right) \cdot{ }^{25,26}$

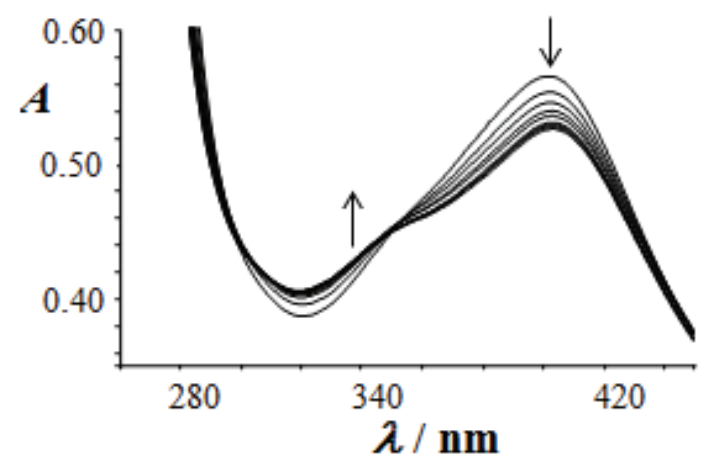

Figure 2. Hydrolysis of $\mathrm{Na}\left[\mathrm{RuCl}_{2}(\mathrm{~N}-\mathrm{Bu}-\mathrm{salim})_{2}\right]$ in phosphate buffer $(\mathrm{pH} 7.50 ; 0.1 \mathrm{M} \mathrm{NaCl}) ; c=5.5 \times 10^{-4} \mathrm{M} ; t=120 \mathrm{~min}$. 


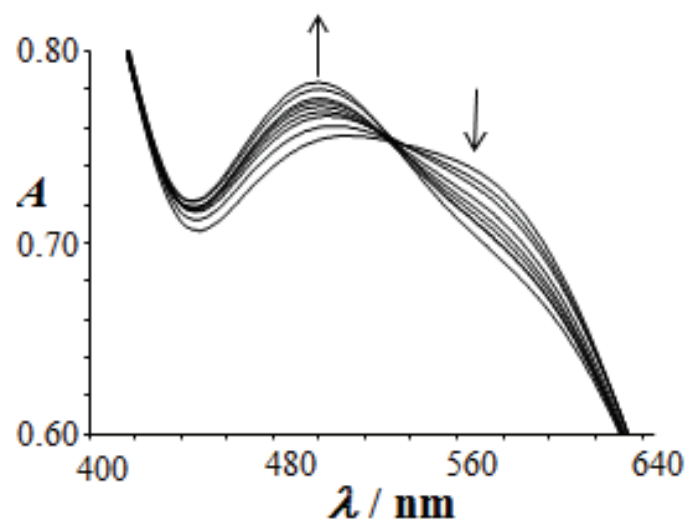

Figure 3. Hydrolysis of $\mathrm{Na}\left[\mathrm{RuCl}_{2}(\mathrm{~N}-\mathrm{Ph}-5-\mathrm{Cl}-\mathrm{salim})_{2}\right]$ in phosphate buffer (pH 7.50; $0.1 \mathrm{M} \mathrm{NaCl}) ; c=1.22 \times 10^{-4} \mathrm{M}$; $t=90 \mathrm{~min}$.

\section{Behavior in Solutions}

Understanding of behavior of compounds in solution, e.g. hydrolysis and electron transfer processes are thought to be very important for potential biological activity and possible antitumor purpose of complex compounds. The hydrolyses of $\mathrm{Na}\left[\mathrm{RuCl}_{2}(\mathrm{~N}-\mathrm{R}-5-\mathrm{X}-\right.$ salim) $)_{2}$ compounds under physiological condition in phosphate buffer $(\mathrm{pH} 7.5 ; 0.1 \mathrm{M} \mathrm{NaCl})$ designates reasonable stabilization of ruthenium(III) after chelation and blue shift of the LMCT bands over the time.

\section{Cyclic Voltammetry Measurements}

$\mathrm{Ru}(\mathrm{III}) / \mathrm{Ru}(\mathrm{II})$ reduction potentials change with ligand environment and is thought to be very important for possible antitumor properties of a compound. The electronic effect of nitrogen from azomethine group and phenolate oxygen on reduction potential is different. More electronegative and smaller oxygen atom, hard in character stabilizes $\mathrm{Ru}(\mathrm{III})$, while nitrogen, as softer, prefers lower oxidation state. Kinetically, Ru(II) compounds are more labile than $\mathrm{Ru}(\mathrm{III})$ which are believed to can be activated by reduction in vivo. Few compounds like gluthation in cells and ascorbic acid in blood are thought to contribute to the reduction in vivo. Cyclic voltammograms of $\mathrm{Na}\left[\mathrm{RuCl}_{2}(\mathrm{~N}-\mathrm{Bu}-\mathrm{salim})_{2}\right]$ and $\mathrm{Na}\left[\mathrm{RuCl}_{2}(\mathrm{~N}-\mathrm{Ph}-5-\mathrm{Cl} \text {-salim) })_{2}\right]$ in DMF solution with sodium perchlorate as supporting electrolyte show

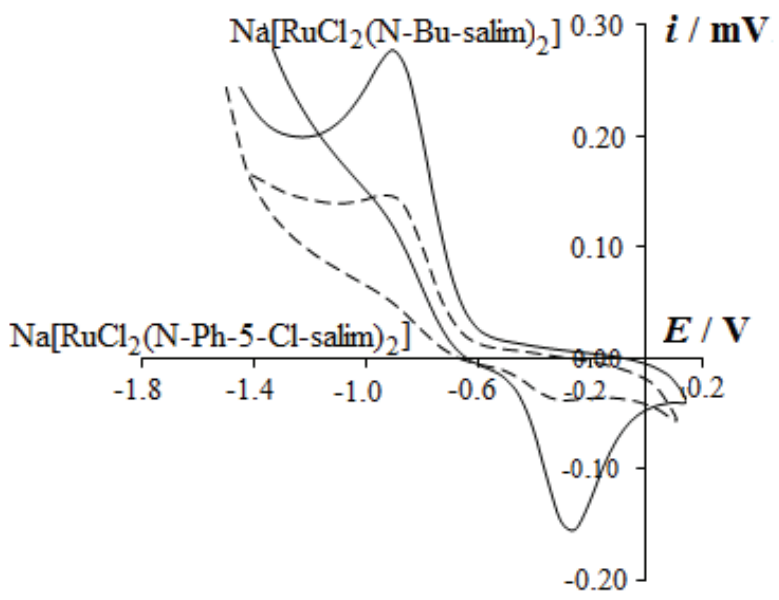

Figure 4. Cyclic voltammograms of $\mathrm{Na}\left[\mathrm{RuCl}_{2}(\mathrm{~N}-\mathrm{Bu}-\mathrm{salim})_{2}\right]$ and $\mathrm{Na}\left[\mathrm{RuCl}_{2}(\mathrm{~N}-\mathrm{Ph}-5-\mathrm{Cl} \text {-salim) })_{2}\right.$; DMF solution, supporting electrolyte $\mathrm{NaClO}_{4}$; working electrode-glassy carbon $v s$ $\mathrm{Ag} / \mathrm{AgCl}$ reference electrode; scan rate $0.8 \mathrm{~V} \mathrm{~s}^{-1} ; E=0.5\left(E_{\mathrm{pa}}\right.$ $\left.+E_{\mathrm{pc}}\right) ; \Delta E_{\mathrm{p}}=E_{\mathrm{pa}}-E_{\mathrm{pc}}$.

defined $E_{\mathrm{pa}}$ anodic peaks at -0.277 and $-0.309 \mathrm{~V}$ respectively, while $E_{\mathrm{pc}}$ cathodic peaks change slightly from -0.901 to $-0.905 \mathrm{~V}$. The half-wave potentials, assigned to $\mathrm{Ru}(\mathrm{III}) / \mathrm{Ru}(\mathrm{II})$ couple, $\left(E_{1 / 2}\right)=-0.607 \mathrm{~V}$ for $\mathrm{Na}\left[\mathrm{RuCl}_{2}(\mathrm{~N}-\mathrm{Bu} \text {-salim })_{2}\right]$ and $\left(E_{1 / 2}\right)=-0.588 \mathrm{~V}$ for $\left.\mathrm{Na}\left[\mathrm{RuCl}_{2} \text { (N-Ph-5-Cl-salim) }\right)_{2}\right]$, in addition to peak-topeak separation values and apparent reduction waves as result of stabilization of $\mathrm{Ru}(\mathrm{III})$ after coordination trough phenolic oxygen from salycilidenimine, ${ }^{27,28}$ suggest the quasi-reversible one-electron transfer processes (Figure 4, Table 1).

\section{CT DNA Binding}

Spectroscopic Study

Interaction of metal complex compounds with DNA is taken as important initial signal about possible evaluation of biological properties of a compound. Activity of ruthenium compounds toward DNA, as a key target for anticancer drugs, may originate from either their covalent interaction with DNA nucleobases or non-covalent binding such as electrostatic interaction of positively charged species with phosphate backbone and intercalation as well. Electronic absorption is very useful method to determine the binding properties of metal complexes

Table 1. Characteristic potentials of $\mathrm{Na}\left[\mathrm{RuCl}_{2}(\mathrm{~N}-\mathrm{Ph}-5-\mathrm{Cl}-\mathrm{salim})_{2}\right]$ and $\mathrm{Na}\left[\mathrm{RuCl}_{2}(\mathrm{~N}-\mathrm{Bu}-\mathrm{salim})_{2}\right]$ from cyclic voltammetry measurements in DMF solution with $\mathrm{NaClO}_{4}$ supporting electrolyte

\begin{tabular}{ccccc}
\hline Complex & $E_{\mathrm{pc}} / \mathrm{V}$ & $E_{\mathrm{pa}} / \mathrm{V}$ & $E_{1 / 2} / \mathrm{V}$ & $\Delta E / \mathrm{V}$ \\
\hline $\mathrm{Na}\left[\mathrm{RuCl}_{2}(\mathrm{~N}-\mathrm{Ph}-5-\mathrm{Cl}-\mathrm{salim})_{2}\right]$ & -0.905 & -0.309 & -0.607 & 0.596 \\
$\mathrm{Na}\left[\mathrm{RuCl}{ }_{2}(\mathrm{~N}-\mathrm{Bu}-\mathrm{salim})_{2}\right]$ & -0.901 & -0.277 & -0.589 & 0.624 \\
\hline
\end{tabular}




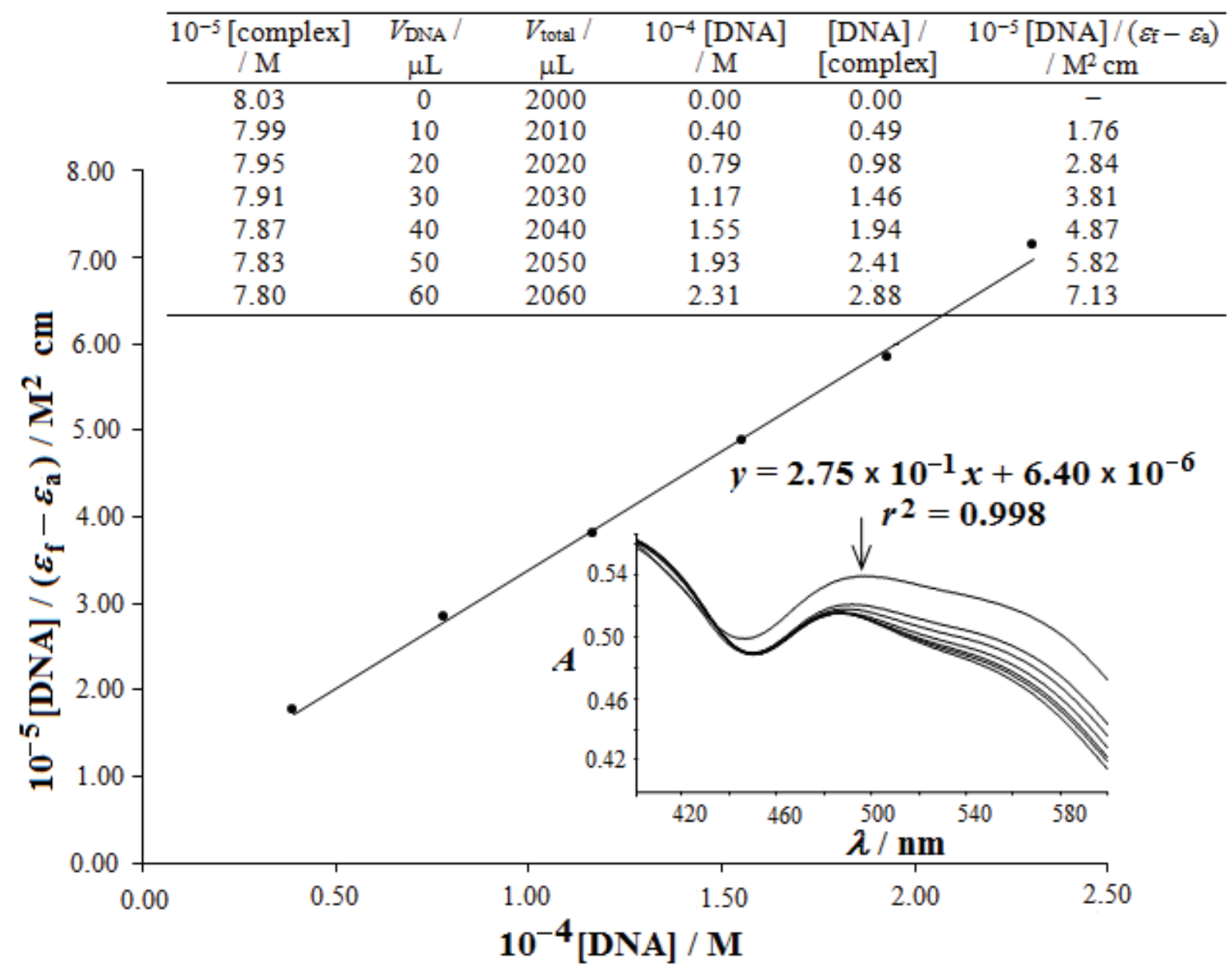

Figure 5. Graphical calculation of $K_{\mathrm{b}}\left(4.32 \times 10^{4} \mathrm{M}^{-1}\right)$ on the basis of spectrophotometric titration of $\mathrm{Na}[\mathrm{RuCl} 2(\mathrm{~N}-\mathrm{Ph}-5-\mathrm{Cl}-$ salim) $)_{2}$ ] by CT DNA. Insets: upper left- experimental data for $K_{\mathrm{b}}$ calculation; bottom right-absorption spectra of $8.03 \times 10^{-5} \mathrm{M}$ $\mathrm{Na}\left[\mathrm{RuCl}_{2}(\mathrm{~N}-\mathrm{Ph}-5-\mathrm{Cl} \text {-salim) })_{2}\right]$ with increasing concentration of CT DNA (stock solution $c=7.98 \times 10^{-3} \mathrm{M}$ ).

with DNA. Spectroscopic study of interaction of $\mathrm{Na}\left[\mathrm{RuCl}_{2}(\mathrm{~N}-\mathrm{Ph}-5-\mathrm{Cl} \text {-salim })_{2}\right]$ and $\mathrm{Na}\left[\mathrm{RuCl}_{2}(\mathrm{~N}-\mathrm{Bu}-\right.$ salim) $)_{2}$ with CT DNA has performed by titration of fixed concentration of complex compounds with increasing concentrations of calf thymus DNA (CT DNA) in the [DNA] / [complex] ratio range 0-2.88 and $0-3.51$, respectively. The constants of binding, $K_{\mathrm{b}}$ were calculated on the basis of equation (1): ${ }^{29}$

$$
\frac{[\text { DNA }]}{\left(\varepsilon_{\mathrm{a}}-\varepsilon_{\mathrm{b}}\right)}=\frac{[\text { DNA }]}{\left(\varepsilon_{\mathrm{b}}-\varepsilon_{\mathrm{f}}\right)}+\frac{1}{K_{\mathrm{b}}\left(\varepsilon_{\mathrm{b}}-\varepsilon_{\mathrm{f}}\right)}
$$

$\varepsilon_{\mathrm{a}}, \varepsilon_{\mathrm{f}}$ and $\varepsilon_{\mathrm{b}}$ represent apparent extinction coefficients for particular measurements $\left(A_{\mathrm{obs}} /\right.$ [DNA]), free complex and completely bound form, respectively. By plotting [DNA] / $\left(\varepsilon_{\mathrm{a}}-\varepsilon_{\mathrm{f}}\right) v s$ [DNA], $K_{\mathrm{b}}$ is obtained as the ratio of the slope and intercept. Experimental data of spectroscopic measurements for interaction metal compoundsDNA are given in Figures 5 and 6.
Weak bathochromic shifts, hypochromism and constant binding values of order $10^{4} \mathrm{M}^{-1}$ indicate that both compounds, containing Schiff bases derived from salicylaldehyde, act as moderate DNA-intercalators. ${ }^{30}$

\section{Electrochemical Study}

Electrochemical method is useful complement method for UV / visible spectroscopic investigation of metal complex intercalative mode binding to DNA. Here we describe electrochemical measurements of redox couples $\mathrm{Ru}^{\mathrm{III}}$ complex / $\mathrm{Ru}^{\mathrm{II}}$ complex in the presence of increasing amounts of CT DNA (Figures 7 and 8, Tables 2 and 3).

Shifts of $E_{1 / 2}$ for both compounds toward more positive values, with increasing concentration of added DNA, suggest different ability of $\mathrm{Ru}(\mathrm{II})$ and $\mathrm{Ru}(\mathrm{III})$ compounds to bind DNA as a result of intercalation mode of binding. Changes in peak-to-peak separation, after addition of DNA, indicate an increase in reversibility of one-electron redox processes. 


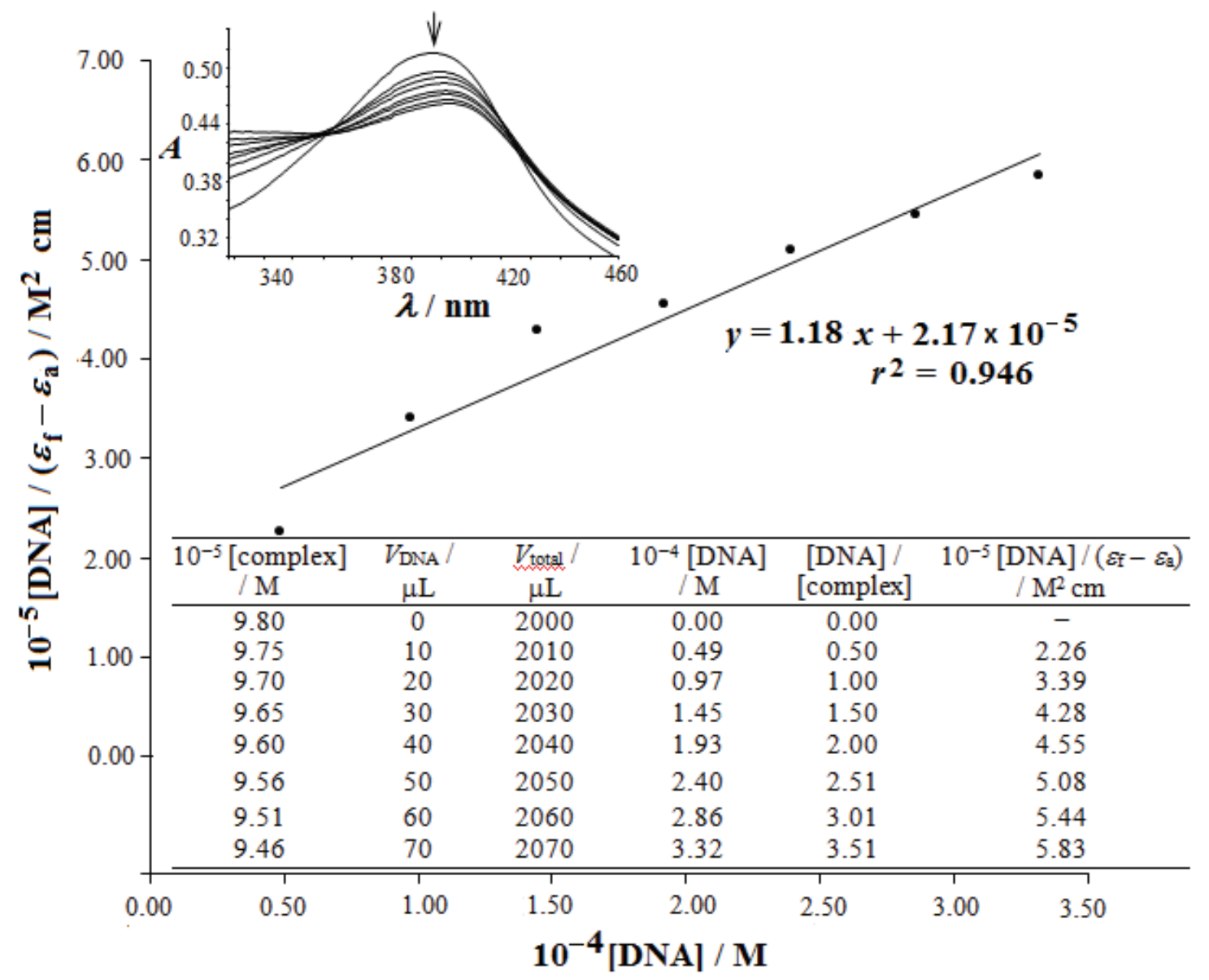

Figure 6. Graphical calculation of $K_{\mathrm{b}}\left(1.81 \times 10^{4} \mathrm{M}^{-1}\right)$ on the basis of spectrophotometric titration of $\mathrm{Na}\left[\mathrm{RuCl}_{2}(\mathrm{~N}-\mathrm{Bu} \text {-salim })_{2}\right]$ by CT DNA. Insets: upper left- absorption spectra of $9.80 \times 10^{-5} \mathrm{M} \mathrm{Na}\left[\mathrm{RuCl}_{2}(\mathrm{~N}-\mathrm{Bu} \text {-salim) })_{2}\right]$ with increasing concentration of CT DNA (stock solution $c=9.75 \times 10^{-3}$ ); bottom right-experimental data for $K_{\mathrm{b}}$ calculation.

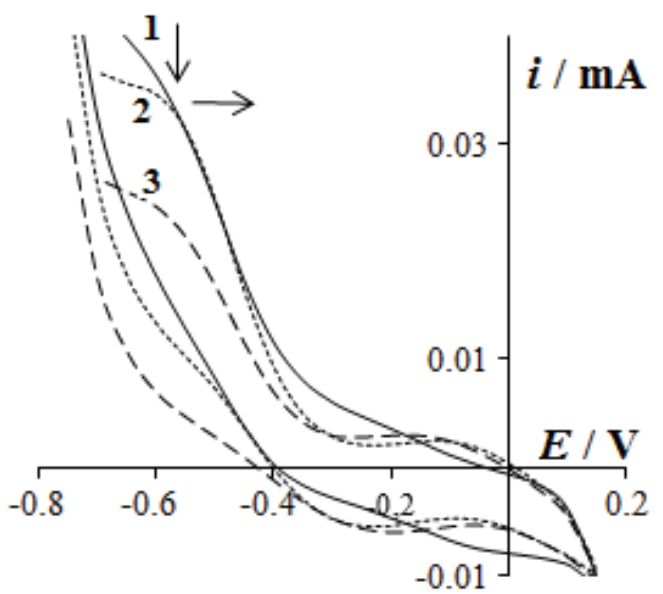

Figure 7. Cyclic voltammograms of $5 \times 10^{-5} \mathrm{M}$ $\mathrm{Na}\left[\mathrm{RuCl}_{2}(\mathrm{~N}-\mathrm{Ph}-5-\mathrm{Cl} \text {-salim })_{2}\right]$ in 1) absence DNA; 2) presence of $9.8 \times 10^{-5} \mathrm{M}$ DNA ([DNA] / [complex] $\left.=2\right)$; 3) presence of $5.88 \times 10^{-4}$ M DNA. ([DNA] / [complex] = 12); $\mathrm{pH} 7.4$, Tris$\mathrm{HCl}$ buffer. Working electrode-glassy carbon $v s \mathrm{Ag} / \mathrm{AgCl}$ reference electrode; scan rate $0.8 \mathrm{~V} \mathrm{~s}^{-1} ; E_{1 / 2}=0.5\left(E_{\mathrm{pa}}+E_{\mathrm{pc}}\right)$; $\Delta E_{\mathrm{p}}=E_{\mathrm{pa}}-E_{\mathrm{pc}}$.

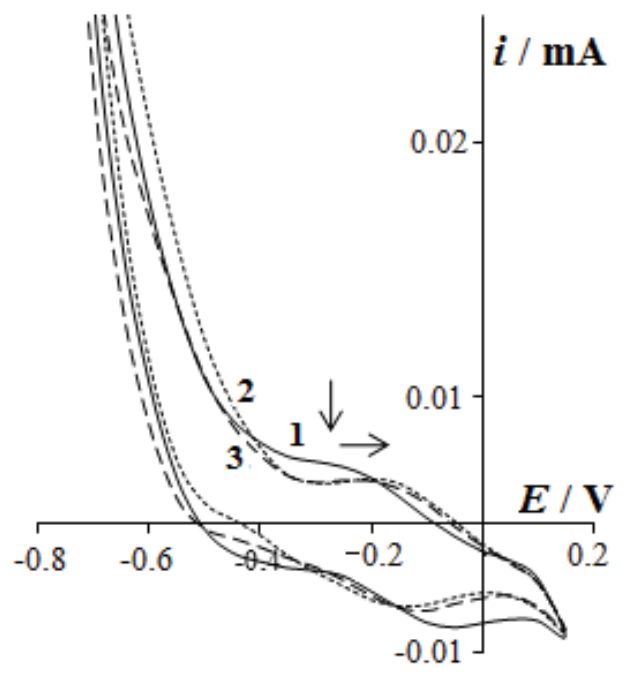

Figure 8. Cyclic voltammograms of $4.9 \times 10^{-5} \mathrm{M}$ $\mathrm{Na}\left[\mathrm{RuCl}_{2}(\mathrm{~N}-\mathrm{Bu} \text {-salim })_{2}\right]$ in 1) absence; 2) presence of $9.8 \times$ $10^{-5} \mathrm{M}$ DNA $([\mathrm{DNA}] /$ [complex] $=2) ; 3$ ) presence of $5.88 \times$ $10^{-4}$ M DNA ([DNA] / [complex] = 12); pH 7.4, Tris-HCl buffer. Working electrode-glassy carbon $v s \mathrm{Ag} / \mathrm{AgCl}$ reference electrode; scan rate $0.8 \mathrm{~V} \mathrm{~s}^{-1} ; E_{1 / 2}=0.5\left(E_{\mathrm{pa}}+E_{\mathrm{pc}}\right)$; $\Delta E_{\mathrm{p}}=E_{\mathrm{pa}}-E_{\mathrm{pc}}$. 
Table 2. Characteristic potentials of $\mathrm{Na}\left[\mathrm{RuCl}_{2}(\mathrm{~N}-\mathrm{Ph}-5-\mathrm{Cl}-\mathrm{salim})_{2}\right]$ in absence CT DNA (1) and presence $(2,3)$ of CT DNA recorded by cyclic voltammetry in Tris- $\mathrm{HCl}$ buffered water solution, $\mathrm{pH} 7.4$

\begin{tabular}{cccccc}
\hline Scan No. & {$[\mathrm{DNA}] /[$ complex $]$} & $E_{\mathrm{pc}} / \mathrm{V}$ & $E_{\mathrm{pa}} / \mathrm{V}$ & $E_{1 / 2} / \mathrm{V}$ & $\Delta E / \mathrm{V}$ \\
\hline 1 & 0 & -0.600 & -0.351 & -0.476 & 0.249 \\
2 & 2 & -0.575 & -0.301 & -0.438 & 0.274 \\
3 & 12 & -0.550 & -0.251 & -0.401 & 0.150 \\
\hline
\end{tabular}

Table 3. Characteristic potentials of $\mathrm{Na}\left[\mathrm{RuCl}_{2}(\mathrm{~N}-\mathrm{Bu}-\mathrm{salim})_{2}\right]$ in absence CT DNA (1) and presence $(2,3)$ of CT DNA recorded by cyclic voltammetry in Tris-HCl buffered water solution, $\mathrm{pH} 7.4$

\begin{tabular}{cccccc}
\hline Scan No. & {$[\mathrm{DNA}] /[$ complex $]$} & $E_{\mathrm{pc}} / \mathrm{V}$ & $E_{\mathrm{pa}} / \mathrm{V}$ & $E_{1 / 2} / \mathrm{V}$ & $\Delta E / \mathrm{V}$ \\
\hline 1 & 0 & -0.251 & -0.105 & -0.178 & 0.146 \\
2 & 2 & -0.185 & -0.155 & -0.170 & 0.030 \\
3 & 12 & -0.171 & -0.141 & -0.156 & 0.030 \\
\hline
\end{tabular}

\section{CONCLUSION}

Some ruthenium complexes with planar and fused aromatic $\pi$-electronic acceptor system or similar aromatic heterocyclic rings are described as DNA intercalators which are able to keep base pair separated distorting double helix structure of DNA. ${ }^{31,32}$ Less extended planar ligands may cause partial intercalation due to omitting of the ancillary ligands and phosphate backbone e.g. in the cases of some 1,10-phenanthroline compounds. ${ }^{33,34}$ Although two easily leaving chlorides in the structures of $\mathrm{Na}\left[\mathrm{RuCl}_{2}(\mathrm{~N}-\mathrm{R}-5-\mathrm{X} \text {-salim })_{2}\right]$ do not exclude a priori covalent binding or even electrostatic interaction of neutral and positively charged complex species produced by loss of chlorides, our spectroscopic and electrochemical investigations suggest an intercalative mode of binding with constant of order $10^{4} \mathrm{M}^{-1}$. Possibly, this is the first report on anionic Ru(III) compounds with Schiff bases derived from salicyladehyde and simple amines which act as DNA intercalators.

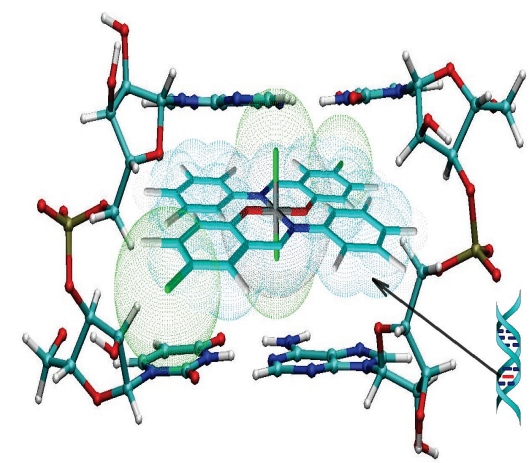

Figure 9. Model of DNA intercalation by sodium dichlorobis $[N$-phenyl-5-chlorosalicylideniminato- $N, O]$ ruthenate(III).
We showed here that ruthenium(III) complexes containing unlike, non-fused kinds of aromatic ligands, such as $N$-phenyl-5-chlorosalicylidenimine and $\mathrm{N}$-butylsalicylidenimine cause intercalation of CT DNA. In the case of $\mathrm{Na}\left[\mathrm{RuCl}_{2}(\mathrm{~N}-\mathrm{Ph}-5-\mathrm{Cl} \text {-salim })_{2}\right]$, with $\pi$-system aromatic ring-azomethine-aromatic ring (two aromates bridged by azometine), $K_{\mathrm{b}}=4.32 \times 10^{4} \mathrm{M}^{-1}$ value indicates good intercalating properties. The variation in structure of Schiff base ligands by altering one aromatic ring with butyl (aromatic - azomethine - butyl) in $\mathrm{Na}\left[\mathrm{RuCl}_{2}(\mathrm{~N}-\mathrm{Bu} \text {-salim })_{2}\right]$ do not affect $K_{\mathrm{b}}$ value significantly $\left(K_{\mathrm{b}}=1.81 \times 10^{4} \mathrm{M}^{-1}\right)$. This implies that aromatic - azomethine part of Schiff base acts as an intercalating chromophore for DNA bases.

\section{REFERENCES}

1. Y. Yamamoto, K. Fukatsu, and H. Nishiyama, Chem. Commun. 48 (2012) 7985-7987.

2. H. Dai, X. Hu, H. Chen, C. Bai, and Z. Zheng, Tetrahedron: Asymmetry 14 (2003) 1467-1472.

3. Y. G. Zhou, W.Tang, W. B. Wang, W. Li, and X. Zhang, J. Am. Chem. Soc. 124 (2002) 4952-4953.

4. P. Barbaro, C. Bianchini, A. Meli, M. Moreno, and F. Vizza, Organometallics 21 (2002) 1430-1437.

5. M. Hartmann and B. K. Keppler, Comments Inorg. Chem. 16 (1995) 339-372.

6. B. K. Keppler, New J. Chem. 14 (1990) 389-403.

7. B. K. Keppler, M. R. Berger, T. Klenner, and M. E. Heim, $A d v$. Drug Res. 19 (1990) 245-253.

8. G. Sava, S. Pacor, G. Mestroni, and E. Alessio, Anticancer Res. 3 (1992) 25-31.

9. G. Sava, S. Pacor, G. Mestroni, and E. Alessio, Clin. Exp. Metastasis 10 (1992)273-280.

10. G. Sava, E. Alessio, E. Bergamo, and G. Mestroni, Top Biol. Inorg. Chem. 1 (1999) 143-169.

11. M. J. Clarke in Met. Ions Biol. Syst. 11 (1980) 231-283. 
12. P. M. T. Piggot, L. A. Hall, A. J. P. White, and D. J. Williams, Inorg. Chim. Acta 357 (2004) 250-258.

13. R. Drozdzak, N. Ledoux, B. Allaert, I. Dragutan, V. Dragutan, and F. Verpoort, Central E. J. of Chem. 3 (2005) 404-416.

14. K. S. Murray, A. M. Van den Bergen, and B. O. West, Aust. J. Chem. 31(1978) 203-207.

15. T. Opstal and F. Verpoort, Angew. Chem. Int. Ed. 42 (2003) 2876-2879.

16. V. Dragutan, I. Dragutan, and F. Verpoort, Platinum Met. Rev. 49 (2005) 33-40.

17. J. B. Binder, I. A. Guzei, and R. T. Raines, Adv. Synth. Catal. 349 (2007) 395-404.

18. J. Chakravarty and S. Bhattachacharya, Polyhedron 15 (1996) 1047-1055.

19. P. S. Chittilappilly and K. K. M. Yusuff Indian J. Chem. 47A (2008) 848-853.

20. E. Kahrović, E. Turkušić, N. Ljubijankić, S. Dehari, D. Dehari, and A. Bajsman, HealthMed. 6 (2012) 1046-1049.

21. E. Kahrović and E. Turkusić, HealthMed. 6 (2012) 699-702.

22. E. Kahrović, S. Dehari, D. Dehari, H. Reçi, S. Begić, and N. Ljubijankić, TTEM 5 (2010) 799-803.

23. K. A. Meadows, F. Liu, J. Sou, B. P. Hudson, and D. R. McMillin, Inorg. Chem. 32 (1993) 2919-2923.
24. E. Kahrović, K. Molčanov, Lj. Tušek Božić, and B. Kojić Prodić, Polyhedron 25 (2006) 2459-2464.

25. S. Kannan and R. Ramesh, Polyhedron 25 (2006) 3095-3103.

26. M. Sivagamasundari and R. Ramesh, Spectrochim. Acta Part A 67 (2007) 256-262.

27. R. Prabhakaran, A. Geetha, M. Thilagavathi, R. Karvembu, Venkatakrishnan, H. Bertagnolli, and K. Natarajan, J. Inorg. Biochem. 98 (2004) 2131-2140.

28. H. Doine, F. F. Stephens, and R. D. Cannon, Bull. Chem. Soc. Japan 58 (1985) 1327-1328.

29. A. M. Pyle, J. P. Rehmann, J. P. Meshoyrer, C. V. Kumar, N. J. Turro, and J. K. Barton, J. Am. Chem. Soc. 111 (1989) 3051-3058.

30. M. Cory, D. D. Mckee, J. Kagan, D. W. Hendry, and J. A. Miller, J. Am. Chem. Soc. 107 (1985) 2528-2536.

31. C. Moucheron and A. Kirsch-De Mesmaeker, J. Phys. Org. Chem. 11 (1998) 577-583.

32. I. Haq, P. Lincoln, D. Suh, B. Norden, B. Chowdhry, and J. Chaires, J. Am. Chem. Soc, 117 (1995) 4788-4796.

33. P. Lincoln and B. Norden, J. Phys. Chem. B 102 (1998) 9583-9594.

34. E. Grueso, G. López-Pérez, M. Castellano, and R. Prado-Gotor, J. Inorg. Biochem. 106 (2012) 1-9. 